\title{
China's Soft Power Diplomacy in Southeast Asia
}

\author{
JOHANNES DRAGSBAEK SCHMIDT
}

\begin{abstract}
This paper is based on a critical comparative political economy perspective that seeks to explain interrelated variables, inconsistencies and potential disruptive effects of China's dramatic rise and entrance into the global political economy. Furthermore, the paper argues that one should in particular focus on the strategically political decision taken by the Chinese leadership to integrate China into the global political economy. During this process, they have allowed Chinese sovereignty, in the economic sphere at least, to become 'perforated', and thus increasing the number of actors in the policy sphere. However, any analysis of China's present overseas economic expansion and foreign policy interests must also consider Chinese realpolitik and the underlying forces that shape these interests. Due to this the present paper includes a security perspective on whether China's reliance on soft power is only a temporary phase on its way to gain regional cum global hegemony. The employed critical comparative political economy perspective is based on an eclectic approach to East and Southeast Asian international relations, employing realism, liberalism and constructivism to analytically differentiate between the different dimensions of the system's modus vivendi. Based on this recognition the paper analyses the new geo-political and geo-economic strategic relationship between China and Southeast Asia. Is Chinese encroachment into Southeast Asia creating greater stability, does it jeopardize US interests and what is the impact on the regime-types, economic restructuring, and the state-civil society relationship?
\end{abstract}

Keywords: Globalisation, regionalism, bilateralism, diaspora, USA, China, Southeast Asia.

\section{Introduction}

Globalization is rapidly changing the overall structure of the international division of labour with the shift of services and manufacturing from the old industrialized economies to the new emerging giants - the global office platform in India and the global factory floor in China. This dislocation in production, services and manufacturing signifies a challenge to the West but is also part and parcel of the inherent imbalances in the world economy. The question for international political economy is where and how countries like India and China fit in? 
One possible answer is that we are entering a new phase of capitalism characterized by a changing production pattern with a shift of economic gravity to the East with corresponding consequences for labour markets, wage levels and living standards in the West; another scenario is related to the substance of the re-emergence of protectionism and a repeat of the all-out tariff battles that led to the Great Depression in the1930s. In short, and very significantly, it is necessary to ask what the responses are of the old economies that are loosing out (Newsweek February 6, 2006)

In their seminal account 'China Awakes', Kristof and Wudunn noted: 'Almost overnight China has changed' (1994: 9). Although their observations primarily focused on internal dynamics and social and political changes, this book revealed the contours of a new 'Asian miracle' based on the premises and earlier experiences of the developmental state as exemplified in the 'command capitalist' strategy in Japan, South Korea and Taiwan. The new literature on China has concentrated on the country's ability and success to attract foreign investment and the accompanying high economic growth rates. China is rapidly ascending to the status of a new economic, as well as political and military power, both regionally and globally. The world's most populous nation of some 1.3 billion people is already the seventh largest economy in terms of GDP as well as the third-biggest trading nation after Germany and the US. China's booming economy attracted FDI worth more than $\$ 60$ billion in 2004, making it the world's biggest FDI recipient. China's sharply growing exports also accumulated more than $\$ 700$ billion in foreign reserves, the second-largest amount in the world after Japan's nearly $\$ 850$ billion. In addition, total employment in China is estimated around 750 million, which is about one and a half times that of the whole of the OECD with enormous labour reserve in agriculture and the informal sector ready to migrate to the coastal areas if, or rather when, labour markets tighten.

Many of these issues are well covered in the academic literature, but what is really new, is the fact that Chinese enterprises themselves are now investing worldwide and across a broad range of economic activities, ranging from trading and banking, to manufacturing and natural resource exploitation. UNCTAD (2005) estimated that China's outward FDI amounted to almost 39 billion in 2004. These data indicate that China has become a global player with operations established in more than 160 countries. This has led many commentators to speculate about the impact of Chinese overseas involvement: 'President Hu Jintao spent more time in Latin America last year than President Bush. And China's vice president, Zeng Qinghong, spent more time in the region last month 
than his US counterpart, Vice President Dick Cheney, over the past four years'(Miami Herald February 2, 2005 cf Landau 2005).

While the Bush administration asked Congress to increase US indebtedness with an additional $\$ 81$ billion in order to keep forces in Afghanistan and Iraq, China offered more than $\$ 50$ billion in investment and credits to countries inside the traditional Monroe Doctrine's shield. That sum surpasses President Kennedy's well known $\$ 20$ billion package for the decade of the Alliance for Progress in the 1960s. In 1975, Chinese trade with Latin America amounted to \$200 million; in 2004, it had reached over $\$ 40$ billion. China has become one of the foremost players in the era of globalization, which US leaders promoted without considering that China might avail itself of this opportunity to move into previously sacrosanct US spheres (Landau 2005).

At the same time, China's very rapid capital accumulation has brought a spectacular rise in its share of world GDP, nearly tripling from 5 percent to 14 percent in a quarter of a century. China alone has made up for the collapsed output share of the ex-Soviet Union and Eastern Europe and much of the downward drift in the share of Europe and Japan (Glyn 2005: 8).

China is using 'soft power' remedies to nurture 'alliances with many developing countries to solidify its position in the World Trade Organization, flex its muscles on the world stage and act as a counterbalance to US power' (Chicago Tribune December 20, 2004 cf Landau 2005). This is also the case in Sub-Saharan Africa and Asia, where governments and business welcome Chinese investment and cooperation as an alternative to Washington's overwhelming obsession with security and 'hard power' related issues.

It seems clear that the Chinese leadership attempts to increase its ability to attract and persuade the world community, regional groups and individual states to comply with its interests. In contrast the present strategy of the Bush administration is an extension of its ability to coerce as a means of implementing US foreign policy exclusively relying on military or economic might. Soft power arises from the attractiveness of a country's culture, political ideals, and policies. Hard power remains crucial in a world of states trying to guard their independence and of non-state groups willing to turn to violence.

The neo-conservatives who advise the president are making a major miscalculation: They focus too heavily on using military power to force other nations to do America's will, and they pay too little heed to our soft power. It is soft power that will help prevent terrorists from recruit- 
ing supporters from among the moderate majority. And it is soft power that will help us deal with critical global issues that require multilateral cooperation among states. And it is soft power that will help the US to deal with critical global issues that require multilateral cooperation among states. That is why it is so essential that America better understands and applies soft power. (Nye 2004a; 2004b; 2003).

Thanks to an overly narrow focus on terrorism and a tendency to place bilateral ties above multilateral relationships, the United States is also losing its influence in Southeast Asia to China. China targets Southeast Asia as a region with a very assertive ASEAN policy.

US security policies following the 11 September 2001 terrorist attacks have played a significant role in its estrangement. However, the problem in fact goes back to the Asian financial crisis of 1997, when the Clinton administration used its influence on the IMF to impose US businessfriendly solutions on the region.

China's decision not to revalue its currency helped stabilize the regional economic order. Shortly after that, China, Japan and South Korea began holding annual discussions with Southeast Asia under the ASEAN-plus-three formula. In 1999, after China's accession to the WTO, ASEAN governments began to worry about the impact of Sino-US trade relations. As a result, China proposed a free trade agreement (FTA) with Southeast Asia, the framework for which was signed in 2002.

It seems that China will soon become ASEAN's second-largest trading partner and bilateral trade could reach US $\$ 200$ billion by 2010. Road and dam building, consolidation of control over the South China Sea, trade and investment combined with overseas development aid (ODA) and military assistance, might eventually result in China's domination of Southeast Asia regardless of Beijing's intentions.

The question is whether we are watching a Chinese replay of the Japanese Flying Geese scheme with the moving of production platforms, FDIs combined with ODA and other diplomatic remedies to the catching-up formation in a pattern similar to that of Japan and later East Asian NICs in the past decades. As a by-product of such a course, China will sooner or later replace the United States as the region's most important strategic partner.

Although the global contradictions and problems provide the overall context, the purpose of this contribution is devoted to provide insight into, and investigate how, these emerging tendencies in the region are spelled out in the triangular relationship between China and the United States in Southeast Asia. 
The approach of the paper relies on a critical comparative international political economy perspective (Cox 1990; Evans \& Stephens 1988a and 1988b; Strange 1994 \& 1996) which seeks to explain the interrelated variables, inconsistencies and disruptive effects of China's dramatic rise and insertion into the global political economy, and the concomitant increase of foreign debt in the United States and its obsession with security and terrorism, respectively. The focus then is broadened into one that not only takes the state alone into consideration but also realizes that: 'Through conscious political decision, elements of the Chinese leadership have chosen to integrate China - or at least, parts of China - into the global political economy. In the process, they have allowed Chinese sovereignty, in the economic sphere at least, to become 'perforated', and increased the number of actors in the policy sphere' (Breslin 2002: 34). However, any analysis of China's present overseas economic expansion and foreign policy interests, must also consider Chinese realpolitik and the underlying forces which shape these interests. It should especially include the fact that the state and local government authorities play a significant role makes it imperative to focus on these factors which are unique to China. Therefore, this paper includes a security perspective on whether China's reliance on soft power is only a temporary phase on its way to regional cum global hegemony (Nye 2006). The critical comparative international political economy perspective is based on an eclectic approach to East and Southeast Asian international relations, employing realism, liberalism and constructivism to analytically differentiate between the different dimensions of the system's modus vivendi (Katzenstein and Okawara 2001/02: 167-185).

Based on this recognition the paper analyses the new geo-political and geo-economic strategic relationship between China and Southeast Asia. Is Chinese encroachment into Southeast Asia creating greater stability, does it jeopardize US interests and what is the impact on the regimetypes, economic restructuring, and the state-civil society relationship?

\section{From Fifth Column to Investor}

China's strategic interest in Southeast Asia goes back centuries exerting suzerainty of the region. In more modern times, such as during the Cold War, the CCP supported insurgencies and communist governments across the region. After the US defeat in Indochina, Beijing became perceived as a direct threat in Vietnam in 1979, when Chinese troops crossed the Sino-Vietnamese border to 'teach Vietnam a lesson' over its invasion and occupation of neighbouring Cambodia. 
During the wave of national liberation struggles in Southeast Asia, the pro-American ruling classes facing strong local communist parties, such as in Indonesia and, revolutionary movements as in Thailand, Malaysia, Philippines and Burma, were receptive to the US policy which portrayed the communist regime in China as the source of the menace to these societies. Today, mutual perception and trust in Sino-ASEAN relations has become important for both sides (Twining 2005). Furthermore, this relationship has strengthened as a consequence 'of the post-Mao leadership's acknowledgement of the ideological and political reliability of Singaporean-style authoritarianism as a worthwhile formula for its own reform process' (Hersh 1998:32).

Thus, the former hostilities have been turned into claims by Beijing that its growing influence in Asia threatens no-one and is to the mutual benefit of all. Zheng Bijan, dean of the influential CCP School says that 'If China does not provide economic opportunities for the region, it will lose the opportunity for a peaceful rise....This is by no means a bid for hegemony' (Brookings 2005).

Some US based observers see China's bilateral engagement with Asia as more political than economic. In a testimony to Congress, Assistant Secretary of State James Kelly claimed that the bilateral agreements mean little in economic terms, 'but they serve notice of how China is using its newly won economic power to expand its presence and political influence among its southern neighbors' (Economy 2005). Such statements are intriguing as they confirm a change in US policy towards China from a friendly competitor to a strategic rival.

China's renewed interest in bilateral engagement with Southeast Asia comes in several spates which will be touched upon in the following. First and foremost, is the increase in development aid and trade volumes; second is the increase of FDI both inward and outward; third is related to China's need for oil, gas and other energy sources; and finally security, defence and diplomacy related matters which cannot be separated from the above. This strategy is embedded in a regional and multilateral umbrella which will be discussed in the second and third sections of the paper.

China's relation with ASEAN is affected by the way the state controls its insertion into the global division of labour and manages its growth and overseas expansion under a dual-trading regime of export promotion and import substitution (Low 2003: 72). One analysis of the impact of Chinese exports on its Asian competitors shows that countries producing consumer goods based on low wages are increasingly suffering negative 
consequences as China's share of world trade grows. Thailand, Cambodia or Laos are not able to compete with base wages as reported from Guangdong at about $\$ 80$ per month and working hours up to 80 per week. The harsh discipline imposed on the Chinese working class and the fact that no independent unions exist translating in appalling working conditions makes it almost impossible for others to compete (Glyn 2005: 12-13).

China's rapid strides in expanding its trade relations with Southeast Asia have been paralleled by the growth of its role as a source of regional investment. As it secures the resources necessary to fuel its growth, Chinese state-owned enterprises (SOEs) are investing heavily in mining, natural gas, and logging opportunities throughout the region. China has committed US $\$ 100$ million in aid and investment to Myanmar and is actively extracting Indonesian natural gas, investing in infrastructure development in the Philippines, establishing rail and highway links with Cambodia, Thailand and Singapore, and promising to dredge part of the Mekong River in Laos and Myanmar to make it suitable for commercial navigation (Economy: 2005: 6). Also private Chinese companies are rapidly joining the SOEs in their search for new investment opportunities.

China tries to reassure its neighbours by claiming that its growing regional importance is a win-win situation for all. Nonetheless, some countries are seeing the benefits moving largely one way. In Myanmar and Cambodia, newly signed deals with China are generating fears of economic dependence and political domination. A trade agreement with Thailand has benefited China's exporters. The first cries of complaint are being heard. 'China has found it relatively easy in recent years to build closer ties to its neighbours with rhetoric about nurturing an East Asian economic community', says David Shambaugh. 'But striking specific deals in specific areas to China's benefit,' he contends, 'will drive a wedge into the diplomatic progress China has made'(Vatikiotis 2004a: 12).

ASEAN-China trade totalled US\$ 39.5 billion and US\$ 41.6 billion respectively in 2000 and 2001. ASEAN's share in China's foreign merchandise trade has been continuously on the rise, increasing from 5.8 percent in 1994 to 8.3 percent in 2000. China is now the sixth biggest trading partner of ASEAN (Tongzon 2005: 191). The two-way trade between China and ASEAN has been growing at a much faster pace than that between Japan and ASEAN in recent years. China-ASEAN trade topped $\$ 100$ billion in 2004, and soared $25 \%$ in the first half of 2005 from a year earlier amid ongoing reductions in tariffs. ASEAN is now China's fourth-largest trading partner behind the European 
Union, the US and Japan. China has already superseded the US as the biggest trading partner of Japan and South Korea. For ASEAN, the US and Japan are still the two biggest trading partners. It is just a matter of time before China will replace both as ASEAN's biggest trading partner (Masaki 2005).

In 2005, ASEAN became China's fourth-largest trading partner behind the European Union, the US and Japan. China has already superseded the US as the biggest trading partner of Japan and South Korea. It is just a matter of time before China will replace the US and Japan as ASEAN's biggest trading partner (Masaki 2005). China's export structure is similar in many respects to that of the ASEAN countries. The PRC is an export rival to its regional neighbours in both labour-intensive products and in goods with greater technological complexity. It is also a competitor in terms of its capacity to attract FDI, which can only increase at the expense of others. In competitive export capacity the PRC is a threat to Thailand and other Southeast Asian economies' market shares in the EU, US and Japan (Holst and Weiss 2005). More intense competition is, therefore, to be expected in third-country markets and ASEAN domestic markets with the establishment of a FTA. China has the lowest unit labour cost and thus a comparative wage advantage in relation to the original ASEAN-6. Even with regard to productivity increase, China's output per worker is growing faster than that in the Philippines, Malaysia and Indonesia (Tongzon 2005: 208).

In smaller countries like Myanmar, Laos and Cambodia, the economic imbalances in the two-way trade are even more apparent. Chinese exports to Myanmar in 2003 were valued to be as high as $\$ 900$ million, compared with $\$ 170$ million in exports from Myanmar into China. Laos absorbed Chinese goods valued at almost $\$ 90$ million in 2003, more than double the 2002 figure. Laotian exports to China meanwhile, amounted to $\$ 8$ million, a $15 \%$ increase (Vatikiotis 2004a: 12).

The situation in Myanmar has clear similarities with Cambodia. China has supplied more than US\$1.6 billion in arms to the country and continues to train a significant number of its military. In March 2004, Chinese vice-Premier Wu Yi was in Yangon to sign 24 pacts on economic and technical cooperation. The Chinese also gave Myanmar \$200 million in low-interest loans. Myanmar's collaboration with China has become so close that some observers claim that Beijing now has a big say in domestic politics. Diplomatic sources say that a common complaint is that China is also dumping cheap goods and demanding special privileges for Chinese companies (Vatikiotis 2004b: 12). China 
wants to secure stable oil and other energy supplies by land, as well as by sea. Speculation is rife about the idea of building an oil pipeline running across Myanmar to Kunming at an estimated cost of $\$ 2$ billion (Masaki 2005). Beijing has a strategic interest and motive behind its dealings with the military junta. In this way, 'China has supplied about US\$ two billion for armaments that have made the Burmese military, the second largest in Southeast Asia after Vietnam, much more technically sophisticated. It has helped the construction of roads, railroads, airfields, ports, and dams....Equally important are unrecorded Chinese influences: Chinese investment - probably the largest of any foreign country - is not found in international statistics' (Frost 2004: 334).

In Cambodia, closer ties to Beijing are spawning economic, political and even military agreements that, some officials fear, ties their country too closely to China. In November 2003, China and Cambodia signed a military agreement under which Beijing provides funds for military training as well as equipment. Cambodia also has accepted aid to help build a railway linking China's Yunnan province to the Cambodian seashore, a strategic priority for Beijing. China has lent Cambodia more than $\$ 45$ million during the past two years, mostly on interest-free terms. For some Cambodians, China has gained a strategic foothold in the country at the expense of Cambodian autonomy and is geo-politically using Cambodia as a buffer against its old foe, Vietnam.

China has also funded the 'North-South Corridor' project to build a highway linking Kunming and Bangkok via Laos. The highway is scheduled to be completely opened to traffic in 2011. Japan balked at funding the project, partly out of fear of lending China a hand in increasing its influence southward on the Indochina peninsula. China also set up a special fund totalling $\$ 20$ million within the ADB for poverty alleviation of the region in 2004 (Masaki 2005).

As an economic, political and cultural power house, China has been adept at overtaking the US in what American political scientist Joseph Nye has dubbed the soft power approach in influencing foreign societies' public opinions, and achieve sympathy.

In a trade related issue, Thailand has asked for support from Beijing, which has promised to train more Thai Chinese language teachers, send native speakers to work in Thai schools, and provide free teaching materials. Whether this has implications for the Thai population's view of China is difficult to discern, but according to one poll in 2003, 76 percent of Thais said that China was Thailand's closest friend as opposed to 9 percent who named the United States (Vaughn 2005: 20). 
These figures imply that there is a clear strategic link between FDI, ODA, military support and a specific focus on export of cultural values.

China is already supporting language training in dozens of countries and reportedly has set a target of raising the number of foreigners studying Mandarin around the world to 100 million by 2010. Currently, more than 30 million people worldwide are studying Mandarin. Since 2004, China's Education Ministry has opened cultural language centres called Confucius Institutes in over 20 countries. In 2004, 110,844 foreigners from 178 countries were studying Mandarin in China, says Xinhua, up 43 percent on 2003. In Southeast Asia, private language schools in Malaysia and Indonesia report rising enrolment in Chinese classes (Montlake 2006). This will also have important spill-over effects on future trade and investment patterns.

Some observers argue that, dynamic economic growth will propel overseas investment in the ASEAN countries, rather than divert FDI from the region. 'China's rapid growth will result in a shift in comparative advantage between the region and China....In the near future, China could well constitute the fourth wave of FDI for Southeast Asia...' (Wong and Chan 2003: 278-279).

In a specific case, which illustrates these points, Chinese firms are reportedly aggressively grabbing local market shares for manufactured items like motorcycles and other consumer products. A Chinese semi-state-owned enterprise TCL invested \$ 10 million in Vietnam to manufacture colour TVs, and within three years edged out foreign rivals - Sony and Samsung - to grab a 15 percent share of the Vietnamese market (Wong and Chan 2003: 297).

Furthermore, the region is host to a relatively big share of Chinese outward investment in non-trading activities. Although there is substantial disagreement about the actual figures, China is now either the third or fourth biggest investor or rapidly climbing to become number one (Frost 2004). Thailand attracted the largest number of Chinese projects and garners the greatest share of investment (Wong and Chan 2003: 286). This rapidly growing flow of outward direct investment from China is primarily state-owned capital, but private Chinese companies have also started to see benefits of investing abroad.

With a Chinese domestic market of 1.3 billion people and plenty of low-cost labour, it might be surprising to find companies looking at investing offshore. Yet, as China grows and competition intensifies, some companies are searching for new markets and try to develop global brands. They may also be aiming to escape regulatory barriers 
and overcapacity at home and, in the most developed areas, higher land and labour costs. Besides with protectionism growing in the US and EU against Chinese exports, a foreign presence can be a clear advantage. Sluggish domestic demand and declining profit margins have in some cases forced manufacturers such as the consumer-goods giant Haier, and the electronics heavyweights Changhong and Konka to establish production bases outside China (Vatiokakis 2004).

Beijing openly shows its desire to promote Chinese overseas investment. Premier Wen Jiabao told a business audience at an ASEAN summit in Bali in October 2003: 'The Chinese government will encourage more of its companies to make investment and establish their businesses in Asian countries' (Vatiokakis 2004). More than 100 Chinese business executives attended an investment forum held in conjunction with the Bali summit and another 40 companies went to an Asia Pacific Economic Forum investment conference in Bangkok the same month.

Despite Premier Wen Jiabao's encouragement, and China's accession to the WTO in late 2002, outward investment still requires official approval. Projects that exceed $\$ 30$ million must go to the State Council, China's cabinet. From Beijing's point of view, lifting all barriers to overseas investment could risk a stampede with capital-rich companies bidding against each other for foreign assets, something that has already happened in the oil industry (Vatikiotis 2004a).

In the more recent past, the bulk of China's overseas investments went primarily to resource-based extraction like in oil and gas in Australia, Indonesia and Thailand. However, now Chinese manufacturers are scouting the region for production platforms to penetrate new markets. Chinese companies now supply Indonesia with electric-power plants and mobile-phone networks, and there are plans to build a 17-hectare China business centre in Jakarta. Chinese investors come to Thailand 'to use the country as a gateway to the ASEAN market,' says BOI Secretary-General Somphong Wanapha (Vatikiotis 2004a).

FDI flows also create problems. While the growth of China hypothetically can be a boon to the rest of the world in the long run, it can also be a cause for concern to Southeast Asia in the short and middle terms. When one considers the fact that China is now expected to capture 6.5 percent of the total FDI for the next five years, the fight for the leftovers is even more severe. 'That is to say, 10 Southeast Asian countries have to compete for the remaining 23.5 percent of the FDI left by China - an average of little more than 2 percent for each country' (Beng 2002). 
These features partly explain why FDI into Southeast Asia has been declining dramatically. In this context, it is easy to understand why ASEAN is now trying to develop a close relationship to China. In 2000, Southeast Asia received just $\$ 10$ billion of foreign capital, a 37 percent decline from the $\$ 16$ billion in 1999 . The figure was $\$ 27$ billion in 1996 and $\$ 19$ billion in 1998. China is the lone beneficiary of the global investment flows while Southeast Asia both on individual country by country basis and as a region has been excluded as a major recipient of global FDI flows (Beng 2002).

This situation means that the region found itself in a catch 22 situation in competing for a share of FDI. Globalization has now turned the world into a beauty contest where the most attractive country or region will stand to gain the most from the flows of funds (Beng 2002). In other words, the region has entered the race-to-the-bottom which implies a decrease in regulation levels of labour relations, as well as an irreversible process that seeks to exert a downward pressure on welfare and social benefits that are presumed to 'inhibit' the incentive to work (Schmidt 2006b).

Indeed, the political establishments of Southeast Asia have to satisfy the expectations of international investors in as many areas as possible. Most notably, they have to strengthen the region's business outlook encompassing transparency, accountability and fair competition. Barring such efforts, FDI will continue to make its way into neighbouring and other regions, to the detriment of Southeast Asia. Capital goes to places where profits can be guaranteed. Right now, unless ASEAN makes Southeast Asia better and safer than China, the flows of future FDI will continue to go north.

It is interesting, in passim, to note with Callahan, that 'it is common to assume that Western multinational corporations are the main investors in China. But diasporic Chinese (including Taiwan and Hong Kong) account for around 80 percent of foreign direct investment in the PRC' and 'Thailand's CP Group is the largest foreign investor in China' (Callahan 2003: 491/500). This is important because although the bulk of outward investment from China remains state-driven, it is indeed plausible that some capital is recycled back through formal and informal diasporic networks.

Moving now to the pertinent issue of energy it has become clear that since 1993 China has become a net importer of crude oil. The Chinese economy is now the world's second-largest oil consumer, after the US. PRC already depends on imports for as much as $40 \%$ of its oil needs, nearly half of which comes from the Middle East. About 80 percent of 
Chinese oil imports are shipped through the Malacca Strait, a waterway notorious for piracy activities (Masaki 2005). Chinese investments in Indonesian oil, gas and power plants will certainly increase further under the Susilo Bambang Yudhyono administration. Jakarta needs FDI urgently and Beijing is promising to deliver. Sino-Indonesian ties have undeniably improved since the 1990 normalisation of relations. Resource and oil rich Indonesia is the most important state in the region for energy-deficient China (Low 2003: 73). The recent signing of the Strategic Partnership Agreement between the two countries in Jakarta on April 24, 2005 is certainly an historical event.

Former President Megawati also focused on closer economic relations with China. A Memorandum of Understanding was signed in 2002 which established an Indonesia-China Energy Forum. This was followed by PetroChina's moves to secure oil fields in Indonesia. China's National Offshore Oil Corporation has also invested in Indonesia's energy sector. In 2002, Indonesia won a contract to supply liquid natural gas to China's Fujian Province. From 1992 to 2002 bilateral trade between Indonesia and China increased from $\$ 2$ billion to $\$ 8$ billion while Chinese investment in Indonesia has grown from \$282 million in 1999 to $\$ 6.8$ billion in 2003. Despite growing economic ties, some analysts see Indonesia's desire to play a leading role within Southeast Asia as potentially creating a geo-political rivalry with China (Vaughn 2005: 27). There is a possibility that the economic relationship may not deliver the benefits to Indonesia that some have come to expect. In fact, 'most analysts agree that China's changing export profile represents a serious threat to the future export competitiveness of most Southeast Asian countries.' According to Chia Siow Yue, 'the export overlap between China and Indonesia is 83 percent and the overlap between China and Singapore is 38 percent' (Hart-Landsberg and Burkett: 88).

Beijing seems intent in pursuing a more active diplomacy around its southern periphery in Southeast Asia, including using 'renminbi diplomacy' and defence co-operation. China's US\$400 million loan to the Philippines for a rail link between Manila and the former US airbase Clark was a carrot for Manila to conclude a defence co-operation agreement with China, although the Philippines remains an important ally of the United States. Manila has since signed an agreement to co-operate in joint oil and gas exploration in the disputed Spratley Islands in the South China Sea. In March 2005, the state-owned oil companies from China, Vietnam, and the Philippines signed a three-year deal to jointly search for oil and gas in the disputed area (Economy 2005: 8). 
During the bilateral quarrel between China and Singapore in 2004, there were rumours that the People's Liberation Army (PLA) had offered to sell Chinese missiles to Malaysia, so as to calm the Malay majority's suspicions of China. Defence co-operation between Jakarta and Beijing has also been touted recently. In concrete terms, China has established a listening post in Myanmar; and in 2002, China signed its first ever border agreement with Vietnam. The two countries also conducted a joint campaign to clear all the landmines along their border, resulting in an increase of border trade to $\$ 4$ billion yuan (Economy: 2005: 7).

Between 1999 and 2000, China has succeeded in signing bilateral political agreements with all ASEAN countries that are aimed at boosting bilateral long-term cooperation in the new century. Moreover, Chinese leaders have made full use of their attendance at almost all multilateral forums, to conduct bilateral meetings with their ASEAN counterparts. For China, the relationship between multilateralism and bilateralism, thus, is a reciprocal one (Cheng-Chwee 2005). In all cases, Beijing has shown real panache and sophistication in dealing diplomatically with individual ASEAN countries, while promoting the much-touted ASEANChina FTA (to be in effect by 2010). It has even managed to implement a foreign policy relying on 'divided to rule' within ASEAN, as illustrated by the recent Sino-Singaporean spat in which Beijing openly favoured and courted Singapore's ASEAN partners, who seemed just as keen to be courted by the Chinese panda (Teo 2005).

\section{Rivals in Regionalism - The New East Asian Community}

Few major international relationships have changed so rapidly as the Chinese-ASEAN rapprochement. Today, all countries of the region embrace and acknowledge publicly the 'one-China' policy. This is to high degree a consequence of better Sino-ASEAN economic ties, but also implies that Taipei will be left with little room to carry out economic diplomacy with Southeast Asia' (Cheng-Chwee 2005: 113). China has shown a definite readiness to use its growing soft power, notably economic leverage and national image and the benefits that accrue from non-material, ideational and cultural influences as a persuasive means to translate its influence into concrete policy interests.

This also implies that ASEAN has witnessed a major conceptual change of its Northern neighbour, from what was termed a 'China threat' to one of a 'benign' China with opportunities. Three factors encouraged this evolution: 1) China's pragmatic policy of political stabilisation denotes a radical political shift in terms of appeasement; 2 ) the real catalyst was an 
outcome of the financial crisis with the Chinese leadership's decision not to devalue the renminbi and the later bonus of surplus trade, accorded to ASEAN countries by Beijing; and 3) The shift - or reduced threat-perception is also due to Beijing's new, active foreign policy and sophisticated diplomacy, based on the smooth internal transitions from Deng Xiaoping to the Jiang Zemin-Zhu Rongji team, and then to the present Hu JintaoWen Jiabao team. Four areas of Beijing's present foreign policy sophistication would include a less pompous, but more pragmatic foreign policy; a growing economic diplomacy; a thrust towards international integration and finally, a struggle for multi-polarity in the world (Teo 2005).

Official relations between China and ASEAN began in July 1991 when Beijing started attending the ASEAN Post-Ministerial Conference. This was followed by various cooperation and partnership agreements with ASEAN, including one on Comprehensive Economic Cooperation, one on the South China Sea, and another on Non-Traditional Security Issues (Beng 2003). Since July 1994, China has also become a full dialogue partner of ASEAN and a member of the ASEAN Regional Forum (ARF).

All these diplomatic partnership agreements help to assure the ASEAN-countries of a more benign China in its outlook and national strategy, and have reduced the previous perception. China is increasingly being recognized not only as a benign power, but also as a responsible actor on the world stage. The key to this policy change has been Beijing's move towards pragmatism, which can be observed in both China's domestic policies and external relations.

Southeast Asia appreciates the normalisation of China's new approach. This is encompassed in a greater sophistication of its foreign policy, and Beijing has deliberately redesigned its overall strategic engagement with the region based on an active policy of strategic friendship with ASEAN countries.

Beijing's new security concept can also be interpreted as aiming at undermining US influence in Southeast Asia and loosen its alliances with Thailand and the Philippines. For example, in 1999, Chinese President Jiang Zemin warned ASEAN states against 'hegemonism and power politics' and 'gunboat diplomacy,' code words for the United States. China is not against playing power politics itself. Chinese inroads in Myanmar, Laos, and Cambodia, through economic aid and military assistance, have become a cause of geo-strategic concern in Vietnam and India, which view China's presence in these countries as creating levers of influence (Thayer 2004: 181). 
Related to the soft power engagement in the region, China has taken a more active role in the ADB and was the prime mover in the establishment of the Boao Forum, the Asian version of Davos. All of these initiatives can be grouped under the rubric of China's new soft power security concept,

which emphasizes cooperative (win-win) security, confidence building, and multilateral engagement. The popularity China has garnered from these activities is no doubt also enhanced by the economic opportunities it presents to regional states. Yet, without China's active engagement of multilateral institutions, its growing bulk might provoke more fear than admiration, much as it did during the early and mid-1990s. Beijing's multilateral engagement has enabled it to improve its material position and its image simultaneously. The fact that this engagement furthers Chinese interests does not make it any less welcome in the region (Heginbotham and Twomey 2005: 246).

The smooth transition from Jiang-Zhu to Hu-Wen - despite the western critique of China's lack of human rights and democracy is considered as another plus by the ASEAN elites. The common impression in the region is that the new generation of Chinese leaders is taking a more business-like and pragmatic approach to foreign affairs.

In 1996, the Chinese leadership engaged a new security concept in an attempt to develop mutual trust and ties of common interest with the aim of promoting genuine security and create regional calm. In the aftermath of the Asian financial crisis, Beijing offered economic assistance to the worst hit economies. In fact, the financial crisis contributed to a major foreign policy change towards a more active Chinese engagement with Asian multilateral security and regional organizations (Foot 2006: 85).

Moreover the crisis changed the regional perception of the US and EU's intentions. 'In this context, the Chinese prime minister Zhu Rongji declared in November 2000 that China stood 'ready to work with other East Asian countries for the reform of the current international financial architecture', and was 'open to all ideas' about financial cooperation in the region' (Sohn 2005: 495).

China not only refrained from devaluing the renminbi but also provided a US $\$ 1$ billion loan bailout of Thailand. Despite objections by the IMF and Washington, in June, 2003, 'China and 10 other Asia-Pacific countries, including five ASEAN members, agreed to establish an Asian Bond Fund worth more than $\$ 1$ billion to help bail out economies in crisis' (Economy: 2005: 6). Soon after in December 2004 China implemented a second bond fund for another $\$ 2$ billion to be invested in Asian currency-denominated government bonds. Indeed it is possible to argue that 
The region - policy elite and wider community alike - perceived IMF policy throughout the late 1990s as humiliating and wrong. In the summer of 1997 the IMF (and the US government) impeded the Japanese initiative to create an Asian liquidity fund. The Asian Monetary Fund (AMF as it would have been called) was explicitly to apply softer conditions than those of the IMF. The AMF's concept corresponded more to that of a 'lender of last resort' than the IMF. Essentially, the AMF idea was about providing unconditional loans to overcome liquidity crises (Dieter \& Higgott 2003: 442).

These initiatives on financial matters were taken in parallel with several moves on the diplomatic front towards ASEAN. In November 2002, China signed two documents: a framework trade agreement designed to establish an ASEAN-China FTA by 2010, and also with ASEAN members, a Declaration on the Conduct of Parties in the South China Sea, renouncing violent means of dealing with disputed sovereignty claims in these waters. In October 2003 it became the first major Asian state outside ASEAN to sign up to the association's Treaty of Amity and Cooperation, the provisions of which likewise rule out the use of force for settling issues in dispute (Foot 2006: 85-86).

'China has expressed ... to work towards signing theSoutheast Asia Nuclear Weapons-free Zone.' The agreement underscores the willingness of China to refrain from the use of force as an instrument of policy (Beng 2003).

As Dieter and Higgott note 'what we are seeing is the contours of a new regionalism in Asia that exhibits three overlapping and complex trends':

1. An interest in monetary regionalism arising from the desire that has emerged, since the financial crises of the late 1990s, to combat financial volatility.

2. An interest in bilateral trade initiatives within the context of the wider multilateral system, largely at the expense of the US endorsed Asia Pacific Economic Cooperation (APEC) style of open regionalism of the 1990s.

3. The emergence of a regional voice beyond that of the sub-regions Southeast and Northeast Asia but more restricted than that of the Pacific as a mega region. The voice of region in the global political economy that is emerging is a new one, an 'East Asian' one (Dieter \& Higgott 2003: 446).

As a consequence, it is of interest to ask whether China is able to keep up its close ties with ASEAN and other regional partners. The following section argues that the main objective is to free itself from the encirclement of the United States. If China's history of foreign relations is taken into further account, Beijing's words can indeed be taken at face value (Beng 2003). Yet the outreach to Southeast Asia 
is not entirely altruistic. It has been worked into the grand Chinese strategic calculation of how to cultivate a multipolar world, in which the US, the current hegemonic power, would loose its dominance. Similarly, China's diplomatic overtures to ASEAN can be interpreted as an attempt to pre-empt member-states from increasing their bilateral security cooperation with the US. It is also a foreign policy goal to prevent Indonesia and Australia from further enhancing their military relationship following the signing of a security pact in 1995. 'To be sure, Beijing is trying to forge a diplomatic strategy to prevent other countries from 'uniting' against China by virtue of a perceived fear of a 'China threat', economic or otherwise. That said, the principal focus has been on countering the lengthening shadow of the United States on the region' (Beng 2003).

This might have serious consequences for the creation of a new regional entity, and not least on the Chinese rivalry with Japan for a leadership role of the region. Although a lot of discussions and energy has been devoted as to whether the East Asian Community (EAC) should be seen as an alternative to the US-led APEC, or be more inclusive towards Canberra and Washington, Japan and China have been in constant rivalry about who should lead the process. This has placed ASEAN in the middle as the two nations have competed for increasing ties with ASEAN. Taken alone as individual countries, the 10 ASEAN members are much smaller than Japan and China, but they wield a strong voice in East Asia when acting as a collective (Masaki 2005).

China has had the upper hand by taking a number of early concrete initiatives. In a geo-economic perspective, the Framework Agreement for Overall Economic Cooperation signed in November 2002 became the starting point for the creation of the world's biggest free trade zone with more than 1.8 billion people. Under that agreement, China and the old ASEAN members will put zero tariffs on most basic products by 2010 . China and Cambodia, Laos, Myanmar and Vietnam will do the same by 2015. A year after the China-ASEAN framework agreement, Japan and ASEAN signed the similar Framework for Comprehensive Economic Partnership in October 2003, starting the process of creating a free trade zone by 2012. Japan has already concluded a FTA with Singapore and reached basic FTA agreements separately with the Philippines, Malaysia and Thailand. Japan's FTA negotiations with Indonesia and the whole of ASEAN got under way in 2005 (Masaki 2005).

In a geo-political perspective, China has taken a number of diplomatic initiatives as well. 
These assertive and at times conflicting Chinese policies apparently reflect a desire to assuage the perception of China among some in ASEAN as the most serious security threat to their countries and thereby to forge closer ties with the grouping. Cementing ties with ASEAN in general - and the joint oil-exploration agreement with Vietnam and the Philippines in particular - is also seen by some as part of efforts to pre-empt a possible US-led containment of China (Masaki 2005).

This illuminates the fact that geo-political concerns have important impacts on geo-economic problems such as the creation of an Asian Monetary Fund and/or the EAC.

Beijing's new soft diplomacy, especially with regard to its Asian neighbours, has evolved into a sophisticated and active soft power policy, and it has to be recognized that China is seeking or at least searching for a hegemonic role regionally, internationally, strategically and diplomatically. Now Beijing's Asian neighbours are accommodating their Chinese companion, but their dreams may turn out to be different.

\section{Understanding China's soft power diplomacy in Southeast Asia}

ASEAN has sought to restrain Chinese power by enmeshing it in regional institutions. Whereas ASEAN is engaging China to tame the aggressive realpolitik that has characterised Chinese foreign relations, Beijing views the same institutions as a way to extend its regional influence and has sought to exclude the US. In planning for the first EAC summit, which was held in Malaysia, China tried to exclude India, Australia and New Zealand, but was overruled by Japan and ASEAN members. As China's regional influence grows, most ASEAN members are working to push against or balance Chinese power. While deepening trade and diplomatic co-operation with Beijing, many members, US allies such as Thailand and the Philippines, key 'swing states' such as Singapore, and emerging regional powers such as Indonesia, have also increased security ties with Washington (Twining 2005).

The question is why the US has changed its policy in the region from a benign power to one almost squarely focusing on hard power balance issues including terrorism as the overall obsession. For Southeast Asia, long under the United States' political and economic influence, times are rapidly moving in a new direction. A decade ago about three-quarters of US investment in East Asia went to Southeast Asia. That figure has now fallen to 10 percent. Approximately 80 percent of US investment in East Asia now goes to China (Thayer 2004: 178). 
The United States remains the region's single biggest destination for exports, and will be for some years to come. This is probably why the White House is on the defensive in terms of coming to grasp with the regional and multilateral setting in East and Southeast Asia. As one observer remarks: "Relations between Southeast Asia and the United States are perhaps best described as 'a policy without a strategy" (Banloi 2003).

Asian leaders are organizing and building new regional institutions precisely to avoid the sort of power politics that America is practicing. Progress has been tenuous but real, and most regional leaders are cautiously optimistic about Asia's future. As long as this remains true, American emphasis on balance-of-power politics will continue to meet with only limited success. Indeed, this approach is likely to be undermined by regional players, who are more interested in participating in economic integration and building regional communities than in divisive balancing behaviour. Most troubling for the United States, it will also cede its leadership role in Asia and limit Washington's ability to influence the future shape of regional institutions in the region (Heginbotham and Twomey 2005: 243-244).

China's ultimate strategic purpose remains a subject of debate and speculation among analysts. Southeast Asia, in this respect, is the sole region adjacent to China in which Chinese influence can most easily expand. A benign interpretation would see China as simply cultivating the sort of stable, peaceful, and prosperous regional environment that is required for its own successful modernization. A more sceptical view sees China playing a long-term game designed to curtail American influence and weave a close-knit economic and security community with China at the centre (Dalpino and Steinberg: 2003: 15).

Beijing is in fact using nationalism and the 'glories of the Chinese civilisation' to instil a sense of unity among Chinese nationals domestically and among the Chinese Diaspora in Southeast Asia. Although Beijing may acknowledge that rampant nationalism could pose a danger to its own internal stability, it has astutely harnessed it to build a new Asian pride and identity, which it hopes could help establish a new Asian system of politics, economics, security and culture within the 'ASEAN+3' framework. The PRC ardently hopes this could be transformed ultimately into an East Asian Community under its leadership (Teo 2005). To realize its peaceful rise, China is using a sophisticated blend of trade, confidence building measures, and development assistance to establish itself as an important regional-cum-global leader. 
Of course the appeal of Confucianism offers Beijing a definite comparative advantage in its soft power approach. Moreover, the relationship China enjoys with the Chinese Diaspora in the region, who dominate the economic and, in some countries like Thailand, increasingly the political scene, is another advantage. The immediate implications of such an approach are that it

would be naive to believe that China is not interested in exerting a dominant influence over its regional hinterland; commercial and financial muscle will eventually be the levers of choice, perhaps spearheaded by a strong regional currency. As much as the Chinese may be more ethnically exclusive than Americans and some Europeans, they are every bit as eager to see Chinese culture and traditions adopted by others - as a mark of civilization. As more and more Chinese tourists visit the region and even begin to dominate the tourist trade, the service sector response will be to tailor to Chinese taste and custom. This will inevitably result in a revival of Chinese culture and language in local communities once believed to have assimilated. Already one of the fastest growing Chinese language media groups is based in Malaysia, where Chinese language education has an unbroken history of more than a century. Up to the present, businesses have catered to a culture that projects modernity and sophistication in a Western guise - this could change and have an impact on U.S. and European influence (Vatikiotis 2003: 75).

The use of culture as a tool of diplomacy highlights the sense of theatre that China skilfully deploys to exaggerate kin, ethnicity and national bonds between the Motherland and the Diaspora. It also

reflects an increased appreciation by the Chinese government of the importance of norms and soft power in diplomacy. Chinese print media, television, music, food, and popular culture are spreading around the region as never before. So, too, are Chinese tourists fanning out across the region, often filling the void left by American tourists staying home after 9/11, the Bali bombing, and tsunami; 800,000 Chinese toured both Thailand and Singapore in 2004 (Shambaugh 2005).

In this way it is safe to say that ethnic Chinese business communities scattered in Southeast Asia have facilitated 'the rearticulation of mainland China into the global economy' not least through their reciprocal involvement in more than 100,000 joint ventures in China (Yeung 2000: 267; 271). It is also arguable that the Chinese Diaspora has been used not just as a financial resource in China to fund revolutions in the past and economic reforms in the present; they have been an important symbolic resource in the construction of Chinese nationalism' (Callahan 2003: 483).

The combination of geo-political and geo-economic strategies and cultural expansion begs an answer to the question: 'what are the impli- 
cations of China's policy of soft power for US influence in the region'? Elizabeth Economy notes the important point that, China's rise to date appears to be less about the 'inevitable conflict of rising power' theory, popular in some circles, than about creeping power transition. Chinese thinkers, themselves, have recognized that the international community is concerned by the potential implications of China's rise and have taken pains to ensure that it will be perceived as non-threatening. This is well illustrated by Li Junru, Vice-President of the Central Party School at the Chinese Communist Party (CCP), who explicitly outlined the benefits to China's neighbours, stating, 'China's rise will not damage the interests of other Asian countries. That is because as China rises, it provides a huge market for its neighbours. At the same time, the achievements of China's development will allow it to support the progress of others in the region' (2005: 3-4).

In order to comprehend the motives and objectives of Chinese pragmatism, it is important to put both bilateral and multilateral diplomatic initiatives and foreign policy into the overall trade and security context and understand the internal and external constraints for a Chinese expansive strategy in Southeast Asia. The region as a whole maintains a trade surplus with China of US $\$ 8$ billion annually, largely from its enormous exports of raw materials and precision machinery. China also agreed to an 'Early Harvest Package' that is perceived by ASEAN as 'largely a concession' to provide benefits through tariff reductions on 573 products including agricultural and manufactured goods. Individual Chinese entrepreneurs are also now expanding China's economic reach throughout Laos and Myanmar. In some areas, locals now use only the Yuan and speak Chinese (Economy: 2005: 4). The forays of Chinese companies fit in with a broader strategic push by Beijing to establish closer economic cooperation with and among Asian countries. Unofficial reports by ASEAN officials claim that the foreign policy aim is part of a broader thrust by China to deploy multilateralism against what it sees as US unilateralist hegemony in the region and the world. 'This is a long-term game that China is playing,' says a senior ASEAN official. 'They want a situation in Southeast Asia that automatically takes into account China's interests. The whole objective of the policy is to avoid strategic encirclement by the U.S.' (Vatikiotis and Hiebert 2003).

Critical voices note that ASEAN's trade with Japan of $\$ 136$ billion and that of the United States of more than $\$ 136$ billion in 2004 exceeds trade with China. At the same time, in both Indonesia and Malaysia, people complain that jobs are being lost to China. Not least because Chinese 
textile exports since January 2005 have increased, thus implying downward competition for Cambodia and Vietnam. A growing mainland Chinese economic presence could also fuel latent resentment against the sizable ethnic Chinese economic elites in the region (Economy 2005: 5). In fact, almost no research has so far been done to investigate the impact of China's FDI on labour markets, environment and social issues and the question is whether China is exporting its own poor labour practices (Frost 2004).

Factors inhibiting Chinese private investment and tourism are sensitive to the treatment of Chinese minorities in Southeast Asia and in particular in the Philippines and Indonesia. The Indonesian racial riots in the aftermath of the financial crisis in 1998 which targeted ethnic Chinese created long-term damage to the 'bamboo network' (Low 2003: 73). There are also cultural impediments when it comes to expansion as noted by a senior ASEAN official: 'Unlike Americans, Chinese don't embrace foreigners - you cannot 'become Chinese" (Vatikiotis 2003: 75).

China's approach has been subtle, using soft power and economic diplomacy to build a benign multilateral framework in the shape of a free-trade agreement with ASEAN. 'China has shown a great deal of sensitivity,' says Singapore Prime Minister Goh Chok Tong. 'China realizes that it is a huge elephant, and even if it treads softly, it can still shake the ground.' One observer notes that 'China is seen by some to be slowly filling the vacuum left behind by the United States in the political, economic and security spheres in the region. This implies that 'U.S. Influence in Asia under Bush is Waning' (Agence France Presse, August 29 , 2004.) and being replaced by China.

Beijing has also stimulated the dynamics of regional cooperation in many other ways. One example is China's enthusiasm for developing the ASEAN-China dialogue into a vibrant web of multilevel and multisector cooperation. As noted above, the 1997 financial crisis was the main catalyst for the creation of a full-fledged diplomatic mechanism spanning summit, ministerial, and senior official levels. As Cheng-Chwee notes, the mechanism has stretched into various semi-state and civil society organizations that include research departments, media outlets, youth organizations, and the business sector. Also cooperation in agriculture, transport infrastructure, as well as energy has been included. Over time, these ties have interwoven into a web of interdependence between China and ASEAN. The PRC has also taken the initiative in pushing for the creation of the Network of East Asia Think-Tanks (NEAT) (2005: 115). These moves are not merely tactical but part of PRCs overall goal to uti- 
lize the ASEAN-plus-three as the main vehicle of East Asian cooperation and the creation of the hybrid East Asian Community. Although there are other factors at play, China has played a decisive role in pushing in that direction. 'China's enthusiasm for East Asian cooperation is clearly driven by its aspiration to shape the direction of the existing regional institutions' (2005: 115-116).

Diplomatically, China's goals and vision in Southeast Asia are clear as it rivals the US and Japan world-wide and regionally. Moreover it may be again considering ASEAN as its own Monroe sphere, as it was during the 400 years of the Chinese tributary system under the MingQing Emperors. Southeast Asian countries appear to be accepting subordination as they seek to profit from the rising China.

\section{Conclusion}

This paper has provided a detailed desk-study based on empirical evidence showing that China has a strategic interest in Southeast Asia. Beijing has engaged the region at all levels, bilaterally and multilaterally with individual states, and been at the forefront in the establishment of new regional institutions.

China has legitimate interests, both geo-economic and geo-strategic, not only in Southeast Asia, but also in East Asia in general. The Chinese leadership has shown a benevolent attitude in its dealing with regional organizations and the contrast between American power politics and Chinese soft power bilateral and multilateral engagement has helped shift world and regional perceptions of both the United States and China. It is interesting to note that a new Asian assertiveness has been brought to the fore, not least helped by active Chinese involvement.

Now that China's power has gradually grown, it has become imperative for Beijing to get up to cultivate good ties to Southeast Asia. The most important side-effect of China's growth is the attendant siphoning of critical FDI away from Southeast Asia. Under such conditions Beijing has to ensure that members of ASEAN remain closely bonded to China, not other stronger and richer powers. This is a sufficient reason for Beijing to support mainland Chinese outward investment into the region and even relocation of production platforms and industries. China's manufacturing prowess is also displacing that of Southeast Asia, indeed, even Japan. This is another reason why Beijing is actively supporting and cultivating increased volumes of trade and providing much needed ODA to poorer Southeast Asian states. Given such figures, coupled with the possibility that China might dominate the entire mass 
manufacturing spectrum, hence leaving little room for Southeast Asia to innovate, it is little wonder that China is trying its best to ensure good ties with Southeast Asia. The forward looking and inclusive character of China's foreign policy is underlined through Beijing's active and repeated assurance that the relevance of the project is less important for China's own interest as it is for 'the sake of the creation of a region structure' (Dieter 2000: 22; Schmidt 2006a).

Beijing's relation to Asia is also a function of the American geo-economic and geo-strategic current hegemony in world affairs. Having observed the relative facility of US military operations conducted in the Persian Gulf and especially in the Balkans and Iraq, it can be observed that neither prospective adversaries nor international organizations pose much of a constraint on Washington and Pentagon's behaviour. By cultivating ties with ASEAN, China can potentially put a check on US influence and accessibility to Southeast Asia.

In a more systematic manner this contribution has shown that bilateral geo-strategic ties at the formal level have deepened in terms of substantial increases in development aid, likewise the trade volume between China and individual Southeast Asian countries will soon surpass trade with Japan, the NICs, the EU and the United States. The same can be said about Chinese FDI pouring into the region's economies. Indeed China is following in the footsteps of Japan and later NICs in pursuing a diplomacy and economic policy based on soft power and a Listian neomercantilist strategy. In reality, China's diplomatic offensive started in the wake of the financial crisis in 1997 and has since then been based on a sophisticated strategy enhancing China's security and defence needs and can best be conceptualized as an attempt to break the US encirclement of mainland China. This also explains its rather successful push to create new regional institutions and its outright strategy of establishing a new Asian identity. It is probably only a matter of time before the AMF - an alternative institution to the IMF - will be formally initiated. The East Asian Community is still in an embryonic stage, but also in this case it will most probably emerge as a real alternative regional institution to the EU, NAFTA and other types of regional organizations. The myriad of Free Trade areas, agreements and measures are, it seems part of a grand design to create a new East Asian entity.

Johannes Dragsbaek Schmidt is Associate Professor at Research Center on Development and International Relations, Aalborg University (jds@ihis.aau.dk) 


\section{REFERENCES:}

Banlaoi, R. C. 2003. Southeast Asian Perspectives on the Rise of China: Regional Security after 9/11, Parameters, Summer

Beng, P. K. 2002. 'Southeast Asia losing FDI fight to China'. Asia Times, 12 Nov. 2002

- 2003. 'ASEAN and China's regional concerns'. Asia Times, 21 Jan. 2003

Breslin, S. 2002. IR, Area Studies and IPE: Rethinking the Study of China's International Relations, Centre for the Study of Globalisation and Regionalisation (CSGR), University of Warwick. Available from: http://www2.warwick.ac.uk/fac/soc/csgr/ research/workingpapers/2002/wp9402.pdf/

Brookings Institution 2005. China's Peacefull Rise: Speeches of Zheng Bijian 1997-2004. Available from: http://www.brookings.edu/fp/events/20050616bijianlunch.pdf

Callahan, A. C. 2003. 'Beyond Cosmopolitanism and Nationalism: Diasporic Chinese and Neo-Nationalism in China and Thailand'. International Organization 57(3) Summer

Cheng-Chwee, K. 2005. 'Multilateralism in China's ASEAN Policy: Its Evolution, Characteristics, and Aspiration'. Contemporary Southeast Asia 27(1).

Cox, R. 1990. Power, Production and World Order. New York: Columbia University Press

Dalpino, C. and D. Steinberg 2003. Georgetown Southeast Asia Survey, 2003-2004, Washington: Georgetown University

Economy, E. 2005. 'China's Rise in Southeast Asia: Implications for Japan and the United States'. Japan Focus, October 6, 2005. http:/ /japanfocus.org/article.asp?id'414

Dieter, H. \& R. Higgott 2003. 'Exploring alternative theories of economic regionalism: from trade to finance in Asian co-operation?'. Review of International Political Economy 10(3) August.

Dieter, H. 2000. 'Monetary Regionalism: Regional Integration without Financial Crises' Available from: http://www2.warwick.ac.uk/fac/soc/csgr/research/keytopic/ global/monreg.pdf/

Evans, P.B. \& J. D. Stephens 1988a. 'Development and the World Economy'. In N.J. Smelser (ed.). Handbook of Sociology. Newbury Park, CA: SAGE Publications, Inc.

Evans, Peter, \& J. D. Stephens 1988b. 'Studying Development since the Sixties: The Emergence of a New Comparative Political Economy'. Theory and Society 17(5) September

Foot, R. 2006. 'Chinese Strategies in a US-hegemonic global order: accommodating and hedging'. International Affairs 82(1).

Frost, S. 2004. 'Chinese outward direct investment in Southeast Asia: how big are the flows and what does it mean for the region?' The Pacific Review 17(3).

Glyn, A. 2005. 'Imbalances of the Global Economy'. New Left Review 34, July-August

Hart-Landsberg, M. and P. Burkett 2004. 'Contradictions of China's Transformation'. Monthly Review 56(3).

Heginbotham, E. And C. P. Twomey 2005. 'America's Bismarckian Asia Policy'. Current History 104(683)September.

Hersh, J. 1998. 'The impact of US strategy: making Southeast Asia safe for Capitalism'. In J. D. Schmidt, J. Hersh and N. Fold (eds.) Social Change in Southeast Asia. London: Longman.

Holst, D. R. and J. Weiss 2005. 'People's Republic of China and its Neighbours: evidence on regional trade and investment effects'. Asian-Pacific Economic Literature 19(2) November

Katzenstein, P. J. and N. Okawara 2001/02. 'Japan, Asian-Pacific Security, and the Case for Analytical Eclecticism'. International Security, 26(3).

Kristof, N. D. and S. Wudunn 1994. China Wakes: The Struggle for the Soul of a Rising Power. London: Nicholas Brealing Publ. 
Johannes Dragsbaek Schmidt

Landau, S. 2005. 'China, Venezuela and the USA - Trouble Brewing'. Progresso Weekly, 26 May to 01, June Edition

Low, L. 2003. 'Multilateralism, Regionalism, Bilateral and Crossregional Free Trade Arrangements: All Paved with Good Intentions for ASEAN?'. Asian Economic Journal 17(1).

Masaki, H. 2005. 'China, Japan tug-of-war over Indochina'. Asia Times, 5 Oct. 2005

Marquardt, E. 2003. 'China's Distant Threat to U.S. Dominance in Asia'. 08 September A report from PINR - Power and Interest News Report. Available from: http:/ / www. pinr.com/report.php?ac=view_report\&report_id=87\&language_id=1

Montlake, S. 2006. 'In Asia, English is useful but Mandarin is rising'. The Christian Science Monitor, 12 Jan.

Newsweek 2006. Stephen Roach. Global Investor - The Hollowing Ring of Davos, February 6

Ott, M. 2004. YaleGlobal Online 'The Great Reverse - Part II Both Southeast Asia and the US have to adjust to China's rising star'. Available from: http:/ / yaleglobal.yale. edu/display.article?id'4473 [accessed 6 Sep. 06]

Nye, J. S. Jr. 2003. 'U.S. Power and Strategy After Iraq'. Foreign Policy, 82(July/August)

- 2004a. Soft Power: The Means to Success in World Politics. Cambridge, MA: Perseus Books Group.

- 2004b. 'The Decline of America's Soft Power'. Foreign Policy, 83(3), Council on Foreign Relation, Washington DC

- (2006) 'Assessing China's power'. The Boston Globe, Number 4, Council on Foreign Relation, Washington DC

Schmidt, J. D. 2006a. 'Regional Social Compacts in Global Perspective'. Paper presented at the UNESCO/MOST International Forum on the Social Sciences - Policy Nexus (IFSP) in Buenos Aires, Argentina and Montevideo, Uruguay 20-24 Feb 2006

- 2006b. 'Flexicurity, Casualisation and Informalisation of Global Labour Markets'. In B. N. Ghosh, (Ed.) Globalization and Conflicts. London: Macmillan,

Shambaugh, D. 2005. YaleGlobal Online. 'Rising Dragon and the American Eagle - Part I'. Available from: http://yaleglobal.yale.edu/display.article?id=5601 [Accessed 20 Apr 05]

Sohn, I. 2005. 'Asian Financial Cooperation: The Problem of Legitimacy in Global Financial Governance'. Global Governance 11(4).

Strange, S. 1994. States and Markets. London: Pinter.

- 1996. The Retreat of the State. Cambridge: Cambridge University Press.

Teo, E. 2005. 'Asian nations hitch their wagons to the Chinese star'. Available from: http:/ / www. onlineopinion.com.au/view.asp?article'3521

Thayer, C. A. 2004. 'Southeast Asia's Marred Miracle'. Current History, April

Tongzon, J. L. 2005. 'ASEAN-China Free Trade Area: A Bane or Boon for ASEAN Countries?'. The World Economy 28(2).

Twining, D. 2005. 'China's Rise Threatens to Divide Asia, Not Unite It'. Financial Times, 22 Aug. 05.

UNCTAD 2002. World Investment Report 2002, Transnational Corporations and Export Competitiveness, Geneva: UNCTAD

UNCTAD 2005. World Investment Report 2005, Transnational Corporations and the Internationalization of R\&D, China, Geneva: UNCTAD. Available from: http:// www.unctad.org/Templates/Page.asp?intItemID'3198\&lang'1

Vatikiotis, M. and M. Hiebert 2003. 'How China Is Building An Empire'. Far Eastern Economic Review, 20 Nov.

Vatikiotis M. 2003. 'Catching the dragon's tail: China and Southeast Asia in the 21st Century'. Contemporary Southeast Asia 25(1). 
- 2004. 'China's Growing Clout Alarms Smaller Neighbours'. Wall Street Journal (Eastern edition). New York, N.Y.: 16 June

- 2004a. 'Outward Bound'. Far Eastern Economic Review 167(5).

- 2004b. 'Chinese Companies Go Global; Red Tape, Protectionism -- Even Costs -- Have More Investing Abroad'. Wall Street Journal (Eastern edition). New York, N.Y.: 30 Jan.

- 2006. 'China, India and the Land Between'. Asia Times, 4 March.

Vaughn B. 2005. 'China-Southeast Asia Relations: Trends, Issues, and Implications for the United States'. CRS Report for Congress - Updated February 8. Available from: http:/ / www.fas.org/sgp/crs/row/RL32688.pdf

Wong J. and S. Chan 2003. 'China's Outward Direct Investment: Expanding Worldwide'. China: An International Journal 1(2) September.

Yeung, Henry Wai-ching 2000. 'Economic Globalization, Crisis and the Emergence of Chinese Business Communities in Southeast Asia'. International Sociology 15(2) June. 